DOI : 10.29408/jit.v4i1.2999 Link : https://dx.doi.org/10.29408/jit.v4i1.2999

\title{
Penerapan Aplikasi Berbasis Android Untuk Ternak Ayam Petelur Sebagai Wadah Untuk Menghubungkan Pemilik Modal Dengan Calon Peternak
}

\author{
Aris Sudianto ${ }^{*}$, Muhamad Sadali2 \\ 1,2Program Studi Teknik Informatika, Universitas Hamzanwadi \\ *sudianto166@gmail.com
}

\begin{abstract}
Abstrak
Ayam petelur merupakan salah satu penghasil protein hewani melalui produksi telurnya, telur mempunyai banyak kandungan zat gizi yang diperlukan oleh tubuh.Kebutuhan telur ayam di NTB tahun 2019 mencapai 1,3 juta butir telur akan tetapi peternak ayam petelur daerah hanya mampu memproduksi sebanyak 6000 butir telur sehingga untuk untuk memenuhi kebutuhan telur pemerintah perlu mendatangkan telur dari daerah lain.Pemerintahpun mendorong masyarakat agar beternak ayam petelur melalui program kampung unggas yaitu salah satu program industrialisasi di bidang peternakan untuk menjadikan NTB mandiri telur .Namun untuk memulai beternak ada beberapa masalah yang menjadi kendala yaitu masalah modal dan lahan.Masyarakat yang memiliki modal tidak memiliki pilihan kemana harus menginvestasikan uangnya ahirnya hanya menyimpan uangnya dibank padahal sebaliknya para peternak yang memiliki lahan membutuhkan modal untuk memulai usaha peternakan. Oleh karena itu penulis memberikan solusi dengan membuat sebuah aplikasi ternak sebagai wadah untuk menghubungkan pemodal dengan calon peternak melalui aplikasi berbasis android agar pemodal bisa dengan mudah mencari calon peternak dan peternak lebih mudah mendapatkan modal untuk memulai beternak ayam petelur.
\end{abstract}

Kata Kunci : Ayam petelur, Aplikasi android,Aplikasi ternak, java, firebase

\begin{abstract}
Laying hens are one of the producers of animal protein through the production of eggs, eggs that contain many nutrients needed by the body. The need for chicken eggs in NTB in 2019 reaches 1.3 million eggs, but regional layer hen breeders are only able to produce as many as 6000 eggs so that to meet the need for eggs, the government needs to bring eggs from other regions. The government also encourages people to raise laying hens through the poultry village program, which is one of the industrialization programs in the livestock sector to make NTB egg independent. However, to start raising livestock there are several problems that become sellers, namely the problem of capital and land. People who have capital do not have the choice of where to invest their money in the end only save their money in a bank whereas on the other hand farmers who own land need capital to start a livestock business. Therefore, the authors provide a solution by creating a well-known application as a place to connect investors with prospective breeders through an Android-based application so that investors can easily find potential breeders and breeders find it easier to get capital to start raising laying hens.
\end{abstract}

Keywords: laying hens, android application, ternak application, java, firebase

\section{Pendahuluan}

Ayam petelur adalah salah satu ternak yang

dapat memenuhi kebutuhan protein hewani,

selain daging tentunya telur yang dihasilkan dapat dikonsumsi oleh manusia. Ayam petelur merupakan ayam betina dewasa yang dipelihara dengan tujuan untuk diambil telurnya.Telur merupakan salah satu sumber protein, telur juga 
DOI : 10.29408/jit.v4i1.2999 Link : https://dx.doi.org/10.29408/jit.v4i1.2999

mempunyai banyak kandungan zat gizi yang diperlukan oleh tubuh. Karena kandungan gizi yang banyak dimiliki telur ini, telur banyak dicari oleh masyarakat.

Sepanjang tahun 2019 kebutuhan telur ayam di NTB mencapai 1,3 juta butir telur, namun peternak dalam daerah hanya mampu memproduksi 600 ribu telur setiap tahun kata Kepala Dinas Peternakan dan Kesehatan Hewan NTB Hj. Budi Septiana dilansir dari lombokpost, sehingga peluang pengembangan budidaya ternak ayam petelur di NTB masih terbuka lebar. Untuk memenuhi kebutuhan telur pemerintah provinsi Nusa Tenggara Barat melakukan program kampung unggas yaitu salah satu program industrialisasi di sektor peternakan untuk mendorong masyarakat beternak ayam petelur agar kebutuhan telur di setiap daerah di NTB terpenuhi dan mewujudkan NTB mandiri telur tanpa harus mendatangkan telur dari provinsi lain.

Untuk memulai terjun dalam peternakan ayam petelur tentunya ada beberapa hal yang sering menjadi kendala masyarakat diantaranya adalah modal dan lahan, Sebagian masyarakat yang memiliki modal untuk berternak ayam petelur terkadang tidak memiliki cukup waktu dan lahan untuk memulai beternak sehingga modal yang dimilikipun hanya bisa disimpan di bank karena tidak memiliki pilihan bagaimana bisa beternak/menginvestasikan modal yang dimiliki tersebut tanpa harus turun langsung mengelola peternakan, dan sebagian masyarakat lainnya yang memiliki lahan dan kemampuan beternak umumnya mengalami kendala pada modal atau keungan karena untuk memulai peternakan ayam petelur membutuhkan modal atau biaya yang cukup besar mulai dari kebutuhan kandang ayam, pakan ayam dan biaya untuk membeli bibit ayam petelur yang siap diternakkan dan pada ahirnya masyarakat akan lebih memilih berhutang atau meminjam uang dari bank yang pastinya akan memiliki bunga sehingga masyarakat akan membayar lebih dari apa yang di pinjam.

Dari permasalahan yang telah dijelaskan diatas maka dibutuhkan sebuah solusi bagaimana menghubungkan orang yang memiliki modal dan ingin beternak ayam petelur namun tidak memiliki waktu dan lahan untuk mengelola peternakan dengan orang yang memiliki lahan dan kemampuan beternak namun belum memiliki modal yang cukup untuk memulai beternak, dan solusi yang penulis tawarkan adalah dengan membuat sebuah aplikasi yang bisa memberikan pemilik modal kemudahan dalam mencari seorang peternak untuk kemudian diberikan modal yang nantinya dikelola untuk berternak ayam petelur.

Berdasarkan hal tersebut maka penelitian ini diberi judul "Penerapan Aplikasi Berbasis Android Untuk Ternak Ayam Petelur Sebagai 
DOI : 10.29408/jit.v4i1.2999 Link : https://dx.doi.org/10.29408/jit.v4i1.2999

Wadah Untuk Menghubungkan Pemilik Modal Dengan Calon Peternak" Dengan harapan agar dapat membantu menyelesaikan permasalahan yang telah diuraikan diatas

\section{Tinjauan Pustaka}

\subsection{Penelitian Terkait}

Beberapa penelitian terkait dengan Aplikasi ternak sebagai wadah untuk menghubungkan pemilik modal dengan calon peternak berbasis android diantaranya adalah sebagai berikut :

Penelititan yang dilakukan oleh Faisal Rahman, M. Husni S dan Wahyu Hidayat pada jurnal yang diberi judul "Aplikasi Peternakan Ayam Broiler Berbasis Android" didapat kesimpulan Aplikasi peternakan ayam broiler berbasis android ini dapat digunakan untuk memberikan penjadwalan jurnal dan SOP harian yang harus dilakukan oleh pegawai sebagai reminder untuk pegawai dalam melaksanakan tugas hariannya didalam kendang. Aplikasi peternakan ayam broiler berbasis android ini mampu menampilkan data stok gudang baik berupa pakan, obat maupun vaksin agar pegawai dapat menggunakan stok yang ada dengan baik, agar dikemudian hari kehabisan stok pada gudang bisa diantisipasi dengan tepat. Mampu membuat aplikasi peternakan ayam broiler yang mampu menampilkan jenis obat apa yang harus diberikan pada ayam dengan mencocokkan gejala yang dialami oleh ayam dengan data gejala yang ada di dalam aplikasi[1].

Selanjutnya adalah penelitian yang dilakukan oleh Putu Huriati, Aldo Erianda dan Fazrol Rozi yang diberi judul "Aplikasi Monitoring Perkembangan Ayam Peterlur Berbasis Android" dari peneltian yang dilakukan didapat kesimpulan Kancer merupakan aplikasi yang dirancang untuk membantu peternak ayam petelur dalam memonitoring perkembangan ayam mereka. Kancer dapat bekerjasama dengan pelaku usaha ayam petelur untuk meningkatkan manajemen perkandangan ayam petelur. Kancer menyimpan dan mengirim data secara realtime. Peternak dapat memantau perkembangan ayam mereka dari jarak jauh selama masih terkoneksi ke internet[2].

\subsection{Landasan Teori}

1. Ayam Petelur

Ayam petelur merupakan salah satu hewan ternak penyumbang protein hewani dengan produk yang dihasilkan yaitu berupa telur yang memiliki kandungan gizi tinggi,nilai gizinya bergantung pada kualitas telur yang dihasilkan[3]. Ayam petelur merupakan ayam betina dewasa yang dipelihara dengan tujuan untuk diambil dan dimanfaatkan telurnya.

Ayam petelur ada dua tipe yaitu tipe petelur ringan yang disebut juga dengan ayam petelur putih. Ayam ini mempunyai badan yang ramping 
DOI : 10.29408/jit.v4i1.2999 Link : https://dx.doi.org/10.29408/jit.v4i1.2999

warna bulu putih bersih dan berjengger merah, ayam ini sensitif terhadap cuaca panas dan keributan. Tipe kedua adalah tipe medium, memiliki ukuran tubuh yang tidak kurus tetapi juga tidak pada saat afkir menghasilkan daging yang cukup banyak ayam. Ayam petelu memiliki beberapa fase untuk siap bertelur yaitu Fase starter, fase grower dan fase layer (produksi).

\section{Android}

Android merupakan sistem operasi untuk telepon seluler yang berbasis linux. Android menyediakan platform terbuka bagi para pengembang untuk menciptakan aplikasi mereka sendiri untuk digunakan oleh bermacam peranti bergerak[4]. Awalnya, Google Inc. membeli Android Inc., pendatang baru yang membuat peranti lunak untuk smartphone. Kemudian untuk mengembangkan Android, dibentuklah open handset alliance, konsorsium dari 34 perusahaan peranti keras, peranti lunak, dan telekomunikasi.

\section{Firebase}

Firebase adalah penyedia layanan cloud dengan back-end sebagai servis yang berbasis di San Fransisco, California. Firebase membuat sejumlah produk untuk pengembangan aplikasi Mobile ataupun web. Firebase didirikan oleh Andrew Lee dan James Tamplin pada tahun 2011 dan diluncurkan dengan cloud database secara realtime di tahun 2012[5].
4. Java

Java adalah sebuah bahasa pemrograman scripting yang sering digunakan dalam pembuatan aplikasi berbasis handphone dan juga dapat digunakan untuk menyediakan akses objek yang disisipkan di aplikasi lain[6]. Java dibuat pada tahun 1991 oleh James Gosling. Salah satu dari proyek pertama yang dikembangkan menggunakan Java adalah sebuah remote kontrol yang diberi nama Star 7 . Pada saat yang sama, World Wide Web dan Internet berkembang sangat cepat.[7] Gosling menyadari bahwa Java dapat digunakan untuk pemrograman Internet. Dengan keluarnya versi 1.2, platform Java akhirnya dipilah-pilah menjadi beberapa edisi, yaitu: The Standard Edition (Java SE), Enterprise Edition (Java EE),Micro Edition (Java ME) dan JavaCard API[8].

\subsection{Tahapan Penelitian}

Adapun tahapan dari penelitian ini meliputi beberapa tahapan diantaranya :

1. Tahapan pengumpulan data-data mengenai kebutuhan peternak dalam memulai usaha peternakan ayam petelur yang mencakup modal usaha, agar calon pemodal mengetahui kebutuhan modal yang akan di siapkan.

2. Tahapan analisis

Tahap analisis meliputi sistem kerja peternak dalam mengelola peternakan 
DOI : 10.29408/jit.v4i1.2999 Link : https://dx.doi.org/10.29408/jit.v4i1.2999

ayam petelur dari perawatan, pemberian pakan, pengelolaan hasil telur hingga dengan proses pendistribusian telur ayam.

3. Tahapan perancangan

Tahapan perancangan dilakukan untuk merancang sistem yang dibutuhkan oleh peternak agar mempermudah dalam mendapatkan akses permodalan dan mengelola peternakan.

4. Tahapan uji coba

Hasil yang telah dilakukan, di uji coba untuk melihat apakah system yang dihasilkan dapat sesuai dengan yang diinginkan peneliti.

5. Evaluasi

Setelah melakukan pengujian terhadap hasil yang dilakukan maka hasil tersebut di evaluasi apakah sudah sesuai dengan yang di inginkan peneliti.

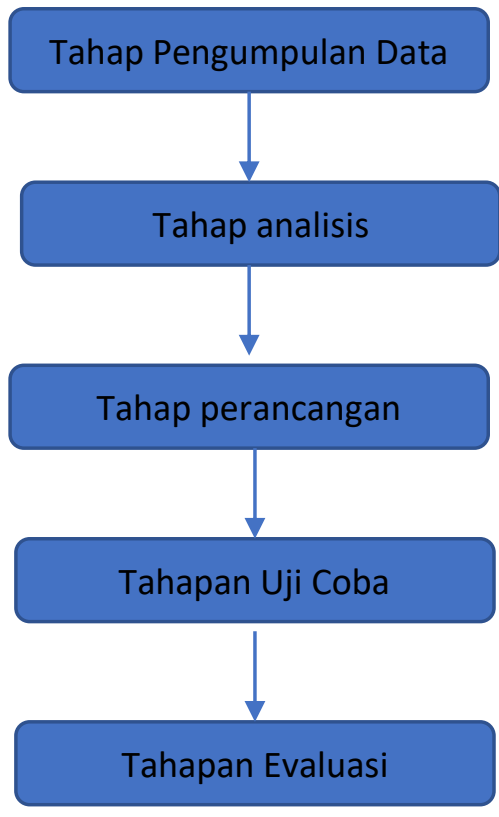

Gambar 4 Tahapan Penelitian

\section{Metode Penelitian}

3.1. Metodologi Penelitian

Untuk mendapatkan informasi yang dibutuhkan serta jelas penulisan dilakukan dengan cara :

\section{Observasi}

Observasi merupakan suatu teknik pengumpulan data melalui pengamatan dan pencatatan terhadap suatu peristiwa yang berhubungan dengan object penelitiannya. Pengamatan dilakukan di peternakan ayam petelur suela milik Muhammad aziz

\section{Wawancara}

Merupakan suatu tekni pengumpulan data melalui tatap muka dan tanya jawab langsung dengan sumber data yaitu pemilik peternakan Muhammad aziz

\section{Studi Pustaka}

Dilakukan untuk menjunjang metode observasi dan wawancara yang telah dilakukan, pengumpulan informasi yang dibutuhkan dilakukan dengan mencari referensi-referensi yang berkaitan dengan kasus serupa yang bisa didapatkan melalui buku dan internet.

\subsection{Lokasi Penelitian}

Penelitian ini dilakukan dengan mengumpulkan sumber data yang di ambil dengan cara melakukan pedekatan langsung kepada narasumber dalam hal ini adalah pak Muhammad Aziz pemilik peternakan ayam petelur yang berada di desa Bile kebar 
DOI : 10.29408/jit.v4i1.2999 Link : https://dx.doi.org/10.29408/jit.v4i1.2999

\section{kecamatan Suela.}

\section{Hasil dan Pembahasan}

Berikut ini adalah hasil aplikasi ternak ayam petelur sebagai wadah untuk menghubungkan pemodal dengan calon peternak berbasis android.

Adapun hasil dari uji coba aplikasi hasil aplikasi ternak ayam petelur berbasis android adalah sebagai berikut :

1. Halaman onboard

Tampilan onboard ini adalah tampilan awal saat pertama kali aplikasi dibuka setelah dilakukan penginstalan tampilan ini akan muncul hanya sekali saja.

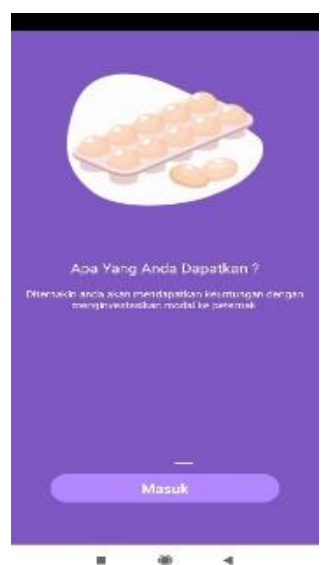

Gambar 5 Halaman onboard

2. Halaman login pemodal

Halaman ini merupakan halaman untuk melakakuan proses login menggunakan akun google yang trsimpan dalam smartphone pengguna.

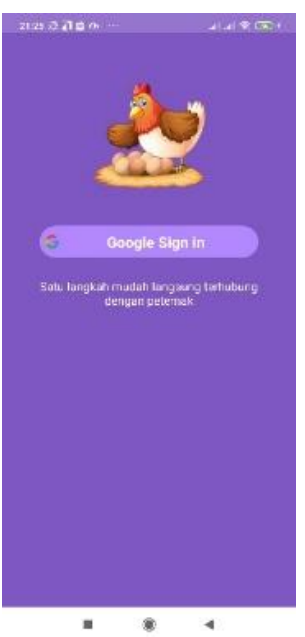

Gambar 6 Halaman login akun google

3. Halaman input data pemodal

Halaman ini adalah halaman untuk proses melengkapi data pemodal, data yang akan diinput berupa alamat email, password nama lengkap, alamat dan nomor handphone.

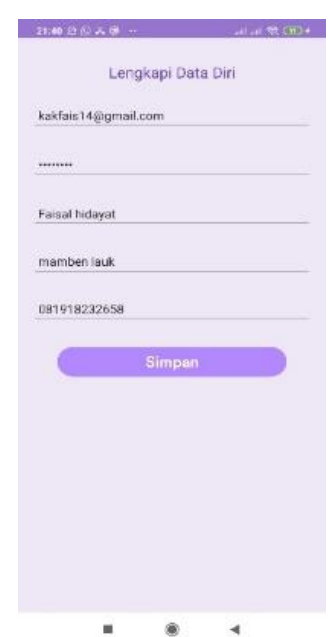

Gambar 7 Halaman input data

4. Halaman dashboard

Halaman dashboard merupakan tampilan halaman utama dari pemodal yang berisi beberapa menu yaitu menu investasi menu peternak menu donasi dan menu penarikan pada 
DOI : 10.29408/jit.v4i1.2999 Link : https://dx.doi.org/10.29408/jit.v4i1.2999

aplikasi ini hanya berfokus pada menu investasi dan menu peternak.

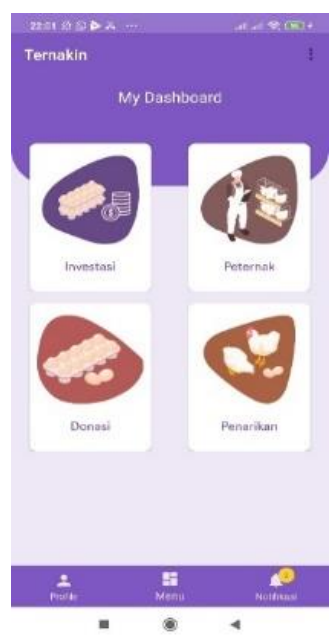

Gambar 8 Halaman dashboard

\section{Halaman investasi peternak}

Halaman investasi peternak merupakan halaman yang menampilkan lis peternak yang telah terdaftar di dalam database.

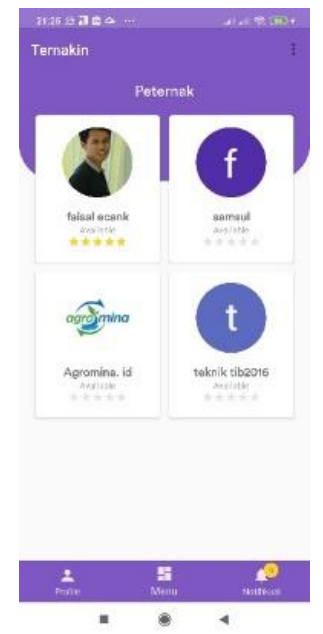

Gambar 9 Halaman investasi peternak

6. Halaman detail peternak

Halaman detail peternak menampilkan data detail dari peternak seperti email, anama lengkap, foto, nomor handphone, jumlah kuota, sisa kuota terisi dan jumlah pemodal yang telah memeberikan modal.

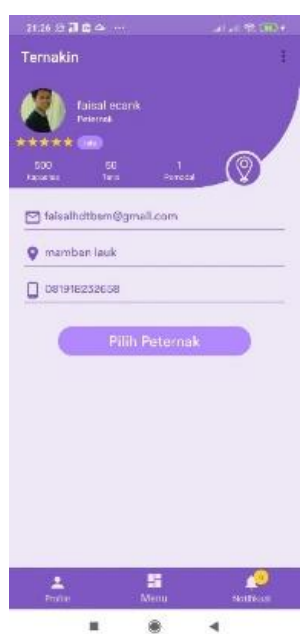

Gambar 10 Halaman detail peternak

7. Halaman jumlah investasi

Halaman jumlah investasi merupakan halaman untuk memilih jumlah ayam yang akan diinvestasikan lengkap dengan biaya yang akan dibayarkan oelh pemodal.

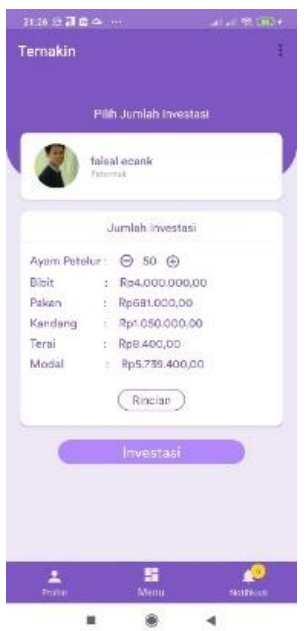

Gambar 11 Halaman jumlah investasi

8. Halaman proses pembayaran

Halaman proses pembayaran terdiri dari 3 halaman yaitu halaman pemilihan bank yang kemudian akan dilanjutkan dengan konfirmasi 
DOI : 10.29408/jit.v4i1.2999 Link : https://dx.doi.org/10.29408/jit.v4i1.2999

pembayaran setelah memilih bank dan halaman untuk mengupload bukti pembayaran.

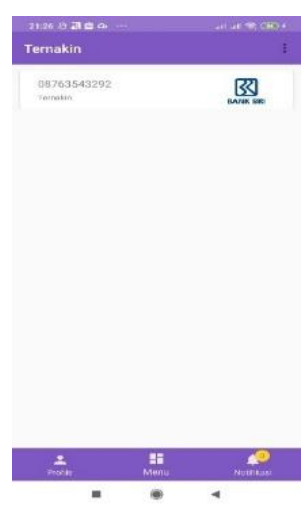

Gambar 12 Halaman proses pembayaran

\section{Halaman konfirmasi admin}

Halaman konfirmasi admin merupakan halaman yang digunakan oleh admin untuk melihat bukti pembayaran yang telah diupload oleh pemodal yang ekmudian akan dilakukan pengecekan untuk memastikan apakah pemabayaran memang benar dilakukan dan admin akan menyetujui atau menolak pesanan berdasarkan bukti yang telah diupload oleh pemodal.
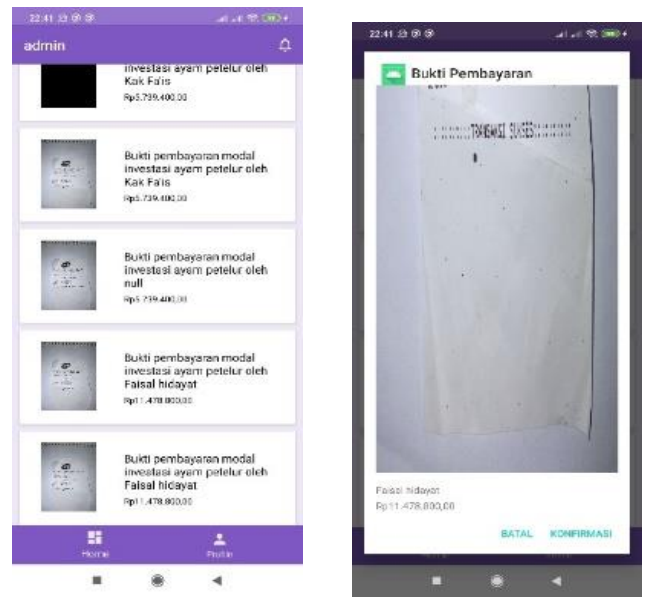

Gambar 13 Halaman konfirmasi admin

10. Halaman laporan peternak

Halaman laporan peternak yaitu halaman yang digunakan peternak untuk memberikan laporan kepada pemodal, pertama peternak akan memilih pemodal yang akan diberikan laporan lalu kemudian membuat laporan yang berisi tanggal laporan, jumlah telur yang dihasilkan, jumlah telur yang dijual dan harga jual telur dan kemudian laporan tersebut akan tersimpan berdasakan tanggal laporannya.
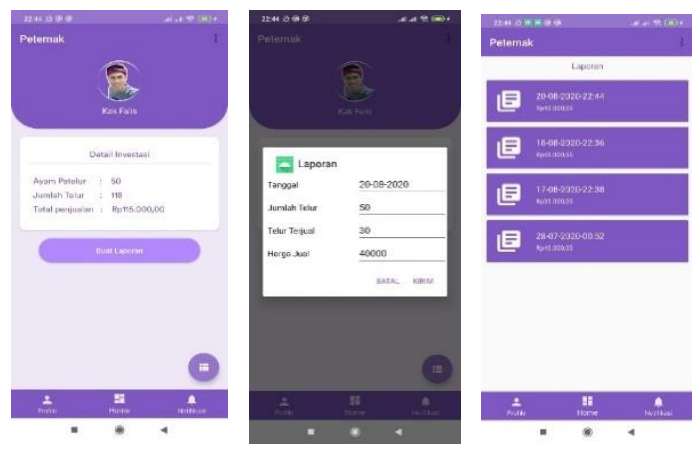

Gambar 14 Halaman laporan peternak

\section{Kesimpulan}

Berdasarkan implementasi dan pembahasan yang telah dilakukan penulis maka terdapat beberapa kesimpulan yang dapat diambil diantaranya adalah sebagai beikut :

1. Peternakan ayam petelur memiliki peluang yang besar karena kebutuhan akan telur ayam yang besar dilombok, akan tetapi pemanfaatan teknologi yang saat ini sanagat pesat belum digunakan secara maksimal untuk memudahkan dalam akses modal kepada peternak maupun pemodal yang ingin bekerjasama dengan peternak dengan cara memberikan modal.

2. Dibutuhkan suatu sistem yang dapat menghubungkan antara pemilik modal yang 
DOI : 10.29408/jit.v4i1.2999 Link : https://dx.doi.org/10.29408/jit.v4i1.2999

ingin meberikan modal dengan peternak yang membutuhkan modal agar bisa berkomunikasi dan bekerjasama dengan baik, sehingga bisa saling menguntungkan pemodal bisa mengembangkan modal miliknya dan peternak bisa memulai peternakan dengan modal yang diberikan.

3. Aplikasi ternak ayam petelur ini dibuat menggunakan Bahasa java dengan IDE android studio untuk membangun aplikasi ini, untuk database menggunakan firbase realtime database yang bisa diakses secara online.

4. Aplikasi ternak ayam petelur meruapakan aplikasi yang dibuat untuk memudahkan pemodal dalam mencari calon peternak dan memudahkan peternak untuk diberikan modal, aplikasi ternak terdiri dari tiga aplikasi yang berjalan di smartphone khususnya android yaitu aplikasi pemodal, aplikasi peternak dan aplikasi admin.

\section{Daftar Pustaka}

[1] Rahman F, Husni S M and Hidayat W 2016 Aplikasi Peternakan Ayam Broiler Berbasis Android (Android Based Application for Broiler Chickens Farm) e-Proceeding Appl. Sci. 2 580-9

[2] Huriati P, Erianda A and Rozi F 2020 aplikasi monitoring perkembangan ayam 2

\section{4-10}

[3] Oriesta P, Harmayanda A, Rosyidi D and Sjofjan O 2016 Evaluation of the quality of eggs from the results of giving several types of commercial feeding layers J-Pal 7 25-32

[4] Aris Sudianto L M S 2019 Penerapan Media Pembelajaran Interaktif Pelajaran Bahasa Indonesia Berbasis Android Untuk Kelas Vii Madrasah Tsanawiyah Nahdlatul Wathan Ketangga Sebagai Upaya Untuk Peningkatkan Minat Belajar Siswa 22 1-8

[5] Sonita A and Fardianitama R F 2018 Aplikasi E-Order Menggunakan Firebase dan Algoritme Knuth Morris Pratt Berbasis Android Pseudocode 5 38-45

[6] Sallaby A F, Utami F H and Arliando Y 2015 Aplikasi widget berbasis java 11

[7] Sudianto A and Ahmadi H 2020 Rancang Bangun Sistem Informasi Penjualan Sparepart Motor Pada Bengkel Vinensi Motor Berbasis Web Guna Meningkatkan Penjualan dan Promosi Produk Pendahuluan Vinensi sepeda motor motor merupakan yang toko cukup kebutuhan suku cadang motor juga dibutuhkan $\mathrm{s}$ Infotek J. Inform. dan Teknol. 3 32-9

[8] Frediyatma S Y 2014 Aplikasi Pemesanan Makanan Berbasis Cloud dengan Platform Android 2 118-26 